\title{
A vida política dos documentos: notas sobre burocratas, políticas e papéis
}

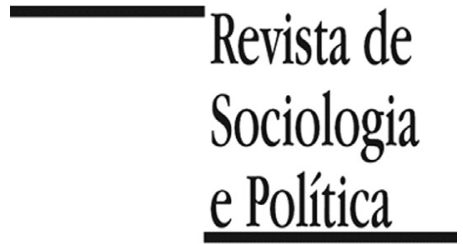

DOI $10.1590 / 1678987319276906$

\section{Telma Hoyler' (iD e Pedro Campos"i⿱一⿻上丨⿹}

RESUMO Introdução: O artigo trata de um tema ainda pouco abordado nos estudos sobre burocracia e políticas públicas, qual seja, os efeitos de documentos sobre a atuação de burocratas, sobre políticas públicas e sobre a política no Estado. Com isso pretendemos abrir um debate sobre a importância dos documentos entendidos como instrumentos de ação pública, bem como aprofundar a investigação sobre burocratas, em especial os de médio escalão e os que serão aqui denominados de back-office. Materiais e Métodos: A pesquisa decorre de uma etnografia das práticas documentais, empreendida durante os quase três anos em que os autores trabalharam em um projeto de reforma das práticas documentais de grande escopo na Prefeitura de São Paulo. Envolveu coleta de informação por meio de observação participante, entrevistas com atores governamentais e análise de legislação e de processos administrativos. Resultados: Observou-se que a incidência conjunta, sobre os burocratas back-office, (1) dos tempos da política decorrentes das interações do incumbente e de seu governo com a sociedade e demais atores políticos institucionais - e (2) do tempo dos papéis - decorrente do conjunto de regras que estabelecem formas de registro das atividades da burocracia, os graus de obrigatoriedade deste registro e de controle disciplinar - é determinante para compreender o comportamento burocrático, orientado para mitigar riscos disciplinares. Em segundo lugar, observou-se que as práticas mobilizadas pelos burocratas refletem agenciamentos dos documentos a partir dos efeitos que estes podem produzir sobre a burocracia: a produção da "verdade", a possibilidade de transposição de soluções a novos contextos e a (não) comprovação de negociações políticas. Discussão: Três implicações resultam desses achados: 1) a dinâmica de atuação dos burocratas explica parte da tendência inercial das burocracias frente às políticas públicas e ressalta a necessidade de amplas negociações e construção de novos marcos documentais para que projetos de inovação possam ocorrer nas burocracias. 2) A promoção de práticas documentais do Estado pode induzir à produção de maior opacidade, e não transparência, ao contrário do que esperam políticas de abertura de dados. 3) Essa abordagem aponta novos caminhos para as teorias sobre criação de capacidades burocráticas e de coordenação. Desse modo, se entendermos o Estado não só a partir da atuação individual de seus agentes e do entrelaçamento de redes pessoais, mas também a partir de como a materialidade dos instrumentos de ação do Estado pode influenciar tais relações, os desafios da direção política, assim como a tarefa de compreendê-lo, se complexificam.

PALAVRAS-CHAVE: documentos; burocratas de médio escalão; burocracia; política pública, instrumentação da ação pública.

Recebido em 4 de Agosto de 2017. Revisado em 23 de Abril de 2018. Aceito em 1 de Agosto de 2018.

\section{Introdução ${ }^{1}$}

\footnotetext{
${ }^{1}$ Os autores agradecem a Gabriela Lotta, Roberto Pires, Adriana Vianna, Marcos Campos e Betina Sarue pela leitura atenta e sugestões substantivas feitas a versões anteriores deste artigo. Agradecem ainda aos comentários e sugestões dos pareceristas anônimos da Revista de Sociologia e Política.
}

$\mathrm{R}$ ecentemente, a cidade de São Paulo enfrentou uma grave crise de abastecimento de medicamentos em suas unidades básicas de saúde. Enquanto a mídia noticiava, por vários meses, a questão e as justificativas genéricas emitidas pela prefeitura, uma equipe de assessores pôs-se a cavar fundo para encontrar a raiz do problema. Os normativos de compras públicas foram analisados, orçamento e planejamento foram revistos, planilhas de despesas recalculadas, o organograma e os cargos foram reposicionados, a proporção entre pregoeiros e volume de compras foi atualizada, a rotina procedimental dos departamentos responsáveis foi modificada.

A despeito de todo o trabalho feito durante mais de três intensivos meses, o desabastecimento continuou até que se superasse um problema central, finalmente identificado: estava vencido o contrato com a transportadora que levava os processos administrativos contendo as requisições de compras de um departamento até outro, localizado em um distrito diferente da cidade, o qual, por sua vez, deveria, finalmente, efetivar a aquisição dos medicamentos. Por algum tempo, nos perguntamos por que a burocracia responsável pela aquisição de 
${ }^{2}$ Weber (1978 p.225) definia a administração burocrática como fundamentalmente a dominação por meio do conhecimento, mas aponta o domínio da escrita como um instrumento de controle e transmissão de informação, observando a especificidade dos documentos como algo desimportante, secundário. medicamentos não realizara a compra, uma vez que se conhecia o problema de abastecimento e sua gravidade à política de saúde. Foi preciso quase três anos trabalhando no governo para responder a essa questão, que veio junto com a compreensão da vida política dos documentos.

Essa pequena narrativa não é um raio em céu de brigadeiro. Embora crises de abastecimento não ocorram todos os dias, a relação dos burocratas com os documentos é atividade rotineira e de mútua constituição, por meio da qual políticas públicas são formuladas e implementadas. Não obstante, políticas públicas ainda são frequentemente apresentadas como caixas-pretas em que se analisam inputs e outputs, negligenciando-se, muitas vezes, os processos internos nos quais os documentos têm função central.

Embora não desconsiderem sua existência, os estudos sobre burocracia têm seguido a esteira weberiana ${ }^{2}$ e tratado os documentos de forma indireta, como instrumentos passivos das organizações, produtos do processo burocrático e meramente derivados de normas e regras formais. Com isso, esses estudos desconsideram o papel constitutivo das atividades burocráticas e das relações sociais formadas por meio dos documentos. Em crítica a essa perspectiva, este estudo afirma que políticas públicas são formadas por pessoas em arranjos institucionais específicos, portando valores, ideias e interesses por sua vez negociados e concretizados em decisões que não são apenas operacionalizadas, mas modificadas pelos documentos. A forma, o conteúdo e a circulação dos documentos influenciam sobremaneira a interação entre burocratas em suas práticas cotidianas, de modo que um conteúdo anteriormente registrado possa chegar a modificar decisões já tomadas ou produzir intensa mobilização para que possa ser efetivada.

Será abordado, especificamente, o nível intermediário das burocracias e suas interações com os documentos. Uma importante parcela da literatura nacional, dedicada a compreender como atores estatais interferem na concretização das políticas públicas, concentra-se na burocracia de alto escalão, destacando-se o nível federal (Lopez 2015; Loureiro 1997; Abrucio, Pedroti \& Pó 2010; Abrucio 2007; Loureiro \& Abrucio 1999; D’Araújo \& Lameirão 2011; Azevedo \& Loureiro 2003). Outra parte concentra-se na burocracia que interage diretamente com o público beneficiário das políticas públicas, conhecidos como burocratas de nível de rua (Lotta 2010; A. Oliveira 2012; Rodrigues 2016; Lima \& D’Ascenzi 2017). No Brasil e no mundo, são recentes os estudos sistemáticos sobre os burocratas que ocupam posição intermediária. Estes têm ganhado espaço na literatura a partir da categoria médio escalão, importante justamente por ser o elo entre o alto escalão e os executores das políticas públicas (Lotta, Pires \& Oliveira 2015). Embora o recorte aqui adotado não seja o mesmo, este estudo tomará tal abordagem como referência.

Pela incipiência do tema, carecemos de estudos que apontem como a camada intermediária opera, a quais constrangimentos está submetida, por quais meios traduz ordens em ações cotidianas, como estabelece padrões de procedimentos e como ocorrem as interações interburocráticas. Abordar tais lacunas a partir de uma "economia política dos papéis" pareceu um caminho profícuo.

Assim, por meio de uma etnografia das práticas documentais no Estado, empreendemos uma investigação que possibilitou as reflexões desse trabalho. Durante os quase três anos em que trabalhamos na prefeitura de São Paulo, os nossos registros - simultaneamente de assessoria e de campo - se dividiam entre tarefas a serem cumpridas, contatos de pessoas, encaminhamentos de reuniões, trechos de diálogo, relato de casos e observações. 
Tendo ocupado cargos em gabinetes de duas secretarias e atuado junto à coordenação de um projeto de larga escala, estivemos em posições privilegiadas quanto ao acesso a burocratas de vários níveis, agendas governamentais e secretarias, de maneira a poder adquirir ancoragens empíricas que extrapolam as particularidades de um único órgão. Para aprofundar a compreensão de algumas situações vivenciadas, adotamos a técnica de traçar o caminho percorrido por pessoas e objetos num campo multisituado (Marcus 1995), identificando conflitos e estudando suas manifestações e relações (Pels \& Salemink 1999).

Na condição de burocratas, participamos de um projeto de implantação do processo administrativo eletrônico, pelo qual tivemos a atribuição de negociar a mudança das práticas de produção e circulação de documentos, até então orientadas para substituir o papel por um formato totalmente eletrônico. Esse trabalho consistiu em um leque de tarefas cujo detalhamento revela o tipo de acesso que tivemos a pessoas, relações e conflitos. Nossas atribuições incluíram elencar os aspectos técnicos, políticos e da ordem das paixões que facilitavam ou dificultavam a implantação do referido sistema e buscar meios de diminuir resistências à sua implementação. Para tanto, era preciso identificar os atores envolvidos em cada tipo de processo administrativo, bem como os documentos produzidos, e compreender o que esses processos significam para os atores e as políticas implementadas em termos de riscos e resultados. A partir disso, junto a uma equipe maior, adaptávamos os procedimentos feitos em papel para o meio eletrônico, validando as alterações junto aos principais atores (afim de diminuir resistências ao uso do novo sistema) e comunicávamos as mudanças para todos os envolvidos na prefeitura.

Essa dupla condição, simultaneamente de observadores e interventores nos processos observados, significou um campo fértil para coletar informações detalhadas e sensíveis aos burocratas, em grande detalhe, sensíveis aos burocratas. Dificilmente essas informações seriam obtidas por métodos alheios ao cotidiano das burocracias. Entretanto, como esperado, os atores resistentes às mudanças ocultavam parcela das informações em função de nossas posições organizacionais. Enfrentamos, nesse sentido, dificuldades metodológicas típicas de estudos em contextos de elites ou de studying up, postuladas por Nader (1972), em que o pesquisador está em posição inferior em termos das dinâmicas de poder ou se encontra nelas imiscuído, sendo preciso trazer à tona as condições de acesso e interlocução, bem como o controle exercido sobre o uso das informações (J. Oliveira 2004). Com esses atores, em função de laços de confiança e de alianças, pudemos realizar conversas específicas depois de se deixarmos os cargos públicos para compreender de maneira mais aprofundada seus posicionamentos.

De modo similar ao que Mosse $(2005 ; 2006)$ descreve, ao simultaneamente trabalhar e pesquisar, adquirimos um conhecimento performativo dos discursos, relações e práticas. Ao mesmo tempo, isso constrangeu nossas possibilidades interpretativas. Embora tenhamos nos debruçado em profundidade para analisar situações do cotidiano, é possível que outros resultados sejam encontrados em situações para as quais não olhamos. Reside aqui justamente a riqueza e a fraqueza do método, a ser contornada com sucessivos estudos sobre o tema.

Ainda a respeito da metodologia, optamos por omitir ou modificar, tanto quanto possível, todos os nomes e gênero das pessoas, as datas e a identificação dos documentos, além de não especificarmos nossas identidades. Ao menos um de nós esteve presente - como interlocutor direto ou observador - em todas as situações narradas. Mantivemos o nome da cidade por considerar que a apresentação de normativos municipais e quantitativo de atores e documentos 
contribui à compreensão do fenômeno, sendo infrutífero maquiar a magnitude dos números de um município como São Paulo. Cabe dizer ainda que algumas situações narradas remontam a outros períodos e se estendem no tempo, não sendo analisado um governo específico. Tais procedimentos decorrem dos dilemas éticos associados a pesquisas deste cunho e entendemos ser nosso dever enquanto pesquisadores assumi-los, ainda que impliquem a omissão de informações que enriqueceriam a análise. Essa dificuldade foi apontada por inúmeros etnógrafos, como Kuschnir (2000).

O artigo está organizado em quatro seções, além da introdução e das conclusões. A próxima seção revisa brevemente a evolução das abordagens analíticas sobre políticas públicas e burocratas, apontando lacunas persistentes quanto à compreensão da atuação da camada intermediária de burocratas. A terceira seção apresenta a dinâmica da produção e circulação de documentos na prefeitura de São Paulo. A quarta seção aborda a interação entre burocratas e documentos, tratando dos riscos e dilemas presentes na produção de processos administrativos. A quinta seção apresenta três cenários de interação entre documentos e burocratas, evidenciando de que maneira a produção e circulação de informações afeta a construção de políticas e a construção da política.

\section{Conectando políticas públicas, burocratas e documentos}

Desde que foi desafiada a visão estática da política - até então interpretada como um processo quase automático de determinação de objetivos, tomada de decisão e implementação - cresceram estudos sobre a implementação como parte do processo político (e.g., Pressman \& Wildavsky 1973; Gunn 1978). Desse modo, o modelo weberiano, que previa um conjunto de arranjos com alto grau de especialização e divisão de trabalho, bem como um comando hierárquico baseado em legitimidade, revelou-se insuficiente para retratar a realidade, por não atentar aos aspectos comportamentais e procedimentais desta forma de organização do Estado. Entender as estruturas de poder, as relações entre atores, a natureza das interações e como as coisas acontecem no Estado e em suas interfaces se tornou imperativo na agenda dos estudos de políticas ${ }^{3}$.

Para uma revisão detalha 2010.

No desenvolvimento do debate anglo-saxão, surgiu a clássica discussão, postulada por Lipsky (1980), a respeito do espaço e do exercício discricionário dos burocratas do nível de rua, focando-se a tomada de decisões na longa cadeia de agentes estatais até chegar aos burocratas implementadores. $\mathrm{O}$ exercício da discricionariedade, de um lado, é uma resposta ao dilema imposto pela pressão da população por atendimento individualizado às suas demandas e, de outro, pela diretriz de uniformização do atendimento feito pelas chefias. Desde então, reuniu-se, no Brasil e no mundo, um grande número de trabalhos empiricamente embasados, preocupados em testar as ideias de Lipsky (1980) e identificar a operação da discricionariedade no serviço social e em outras burocracias. Apesar dos importantes avanços na compreensão das políticas, essa trajetória é bastante pautada pela lógica do public management, levando a problematizações que reforçam o binômio controle-discricionariedade, tendo, ainda, pouco a informar sobre os efeitos que a interação entre burocratas, usuários, práticas e condições materiais tem sobre os resultados das políticas (Pires 2016).

Em paralelo, os estudos sobre burocracia na França, a partir da denominada sociologia de guichê, tratam do efeito das interações entre burocracias e público na (re)produção de desigualdades sociais. Essa abordagem trouxe importantes contribuições analíticas sobre o desenho das práticas para a conformação cotidiana das políticas públicas, ao observar as formas como esses encontros são experimentadas pelos atores. Ao adotar o guichê de uma burocracia como lugar de observação das interações na produção dos serviços, Weller (1997; 
${ }^{4}$ Termo adotado na esteira de trabalhos como os de Callon (1986) e Akrich, Callon e Latour (1988).

\footnotetext{
${ }^{5}$ Identificamos que diversos cargos de livre provimento com classificação de chefia eram ocupados, na prática, por pessoas que exerciam função de assessores. Da mesma maneira, assessores especiais do próprio gabinete eram muitas vezes designados para a coordenação de projetos interdepartamentais que acabavam por destituir chefes
}

1999) analisou como a produção de acordos entre burocratas do guichê e seus atendidos não se baseia apenas em atividades de comunicação, mas em longas cadeias de interação entre seres humanos (burocratas e usuários) e não humanos (documentos, regras, códigos, sistemas informatizados, bancos de dados, formulários, entre outros), formando redes sociotécnicas ${ }^{4}$. De acordo com Weller (1999), burocratas precisam mobilizar seres heterogêneos, como as pessoas diretamente envolvidas e aqueles encarnados em textos, computadores, normas etc., constituindo uma "rede" que os permitiria encontrar os caminhos possíveis para a solução ou estabilização de problemas materializados em documentos estatais. Pires (2016) destaca o potencial dessa vertente em extrapolar a usual dicotomia entre o formal e o informal no trabalho burocrático, permitindo estabelecer continuidades entre ordem técnica e trabalho humano, entre regras formais e a atividade interpretativa das pessoas, sem a qual não seria possível ativar e fazer a rede girar.

Para Weller (1999), a observação do trabalho administrativo em ação exige, então, apreender a importância da linguagem e também dos objetos, dos corpos, do ambiente em que se articula a atividade e o agenciamento possível de atores e recursos. Embora incorpore novos elementos para a compreensão da implantação de políticas públicas, essa perspectiva não observa a interação entre burocracias e suas dinâmicas organizacionais.

Esse breve apanhado do debate evidencia um importante avanço na compreensão dos processos de produção das políticas públicas. O olhar sobre a cadeia hierárquica trazida pela literatura anglo-saxã ressalta dilemas dos burocratas e suas interações, e a literatura francesa introduz elementos materiais na dinâmica relacional. Essa discussão, contudo, ainda está muito restrita à camada de burocratas que interage diretamente com a população. Apenas recentemente iniciou-se um esforço para compreender quem são burocratas de médio escalão (Kuratko et al., 2005; Lotta, Pires \& Oliveira 2015) em suas categorias equivalentes como policy analysts (Page \& Jenkins 2005), public managers (Howlett 2011; Meyer et al., 2013) e middle managers (Floyd \& Wooldridge 1992; Thomas \& Linstead 2002).

Essa polissemia revela uma instabilidade na delimitação da categoria. Por vezes se está observando o mesmo fenômeno com nomes distintos, em outras se trata, de fato, de um problema diferente, cuja delimitação também varia com a estrutura administrativa em questão. Uma das opções teóricas é definir médio escalão como a camada que serve de elo entre o alto escalão e o nível de rua (Lotta, Pires \& Oliveira 2015). Em termos empíricos, um dos indicadores para caracterizar o burocrata como alguém que cumpre a função de ser elo é se ele chefia uma equipe e, portanto, recebe ordens do alto escalão e repassa aos implementadores da política, na ponta.

Embora essa seja uma boa aproximação, a dinâmica organizacional e as instituições informais muitas vezes levam a situações em que burocratas conectam escalões sem estarem designados formalmente para tanto e, em outras situações, chefiam formalmente equipes sem desempenhar, de fato, a função de conectar decisões do alto escalão com a execução $0^{5}$. Além disso, em burocracias complexas e de grande porte, a equipe chefiada pelo médio escalão não necessariamente é do nível de rua e não lida diretamente com a população. Ainda que consideremos tal delimitação do médio escalão, a literatura ainda não estudou outra camada, que opera entre o médio escalão e o nível de rua. A relação dessa camada com os documentos é fundamental e a denominamos de back-office.

Este estudo, portanto, trata tanto do médio escalão como do back-office. Quando ambas forem tratadas conjuntamente, serão denominadas "camada intermediária da burocracia". Tal recorte procura privilegiar os aspectos 
de equipes de suas funções de coordenação. comuns da interação com os documentos, os quais diferem substantivamente em relação às demais camadas, tanto em termos dos riscos a que estão submetidas, como das estratégias de negociação.

No alto escalão, as preocupações com o desenho geral da política e o arranjo político que a sustenta são dominantes; no nível de rua ou no guichê, as preocupações decorrentes da interação com o público e com o controle superior se destacam. Nestes casos, os documentos têm um lugar secundário. A camada intermediária, por sua vez, tem os documentos como principal objeto de preocupação.

Tendo definido o recorte do objeto, analisamos seu comportamento. Lotta, Pires e Oliveira (2015) destacam três abordagens a partir das quais o comportamento burocrático já foi analisado: 1) a estrutural, que reporta um comportamento previsível derivado de uma hierarquia bem definida (Weber 1978); (2) a individual, em que o foco está no cálculo racional do burocrata para maximizar benefícios e evitar sanções (Buchanan \& Tullock 1962; Moe 1984); (3) a relacional, que enfatiza a dinâmica interna e entre grupos e coalizão de interesses (Kuratko et al., 2005; Heimer 2013; Huising \& Silbey 2011).

Este estudo se interessa em observar, à semelhança do que foi postulado por Wise (2004), como tais perspectivas podem se complementar a fim de construir um quadro mais completo acerca da dinâmica interna das burocracias. Tomando de empréstimo a perspectiva de Weller (1997), acrescenta ainda o elemento material como fator importante para compreender as burocracias e sua relação com as políticas. Argumenta-se que é por meio de formas materiais de documentação e comunicação que as estruturas e relações são operadas e que os burocratas dessa camada intermediária avaliam uma parte importante dos riscos a que estão submetidos.

Os documentos demoraram a ser tratados como objetos de estudo em si, sendo vistos anteriormente como meros meios de registro. Para Riles (2006), isso pode ser parcialmente explicado pelo próprio método de trabalho do cientista social, que incorpora a leitura de documentos para acessar seus objetos de estudo, naturalizando-os como fonte de registros. Nas últimas décadas, surgiu na antropologia uma literatura sobre a materialidade do Estado que, ao questionar pressupostos weberianos de Estado quanto à sua unicidade e coerência, procurou analisar as formas pelas quais tais crenças são produzidas (Das 2004; Sharma \& Gupta 2006; Gupta 2012). Nessa esteira, examinando o Estado em tempos de guerra, Kafka (2012) olhou para como os "papers" (paperwork) são capazes de produzir síncopes no ritmo do Estado e desestabilizar suas estruturas mesmo a partir de erros pequenos. Influenciado pela ideia de regimes de valor e de pressupostos compartilhados durante a troca de commodities de Appadurai (1986), bem como pela perspectiva sociotécnica, Hull (2012) estudou os artefatos gráficos do Estado (formas materiais de documentação e comunicação), constituídos de elementos próprios e também por associações de pessoas, lugares e outras coisas. Para restaurar analiticamente a função do papel, o autor sugere olhar para em vez de através deles, no sentido de que documentos não são fornecedores neutros de discurso, mas mediadores que moldam os significados de seu conteúdo e se inscrevem neles.

Notamos que as discussões sobre políticas públicas, burocracias e agentes implementadores, realizadas principalmente pela Ciência Política, e as discussões sobre artefatos, empreendidas majoritariamente pela Antropologia e Sociologia, têm ainda encontrado poucos pontos de intersecção (dentre os quais vale citar Campos, 2018). Este artigo procura conciliar as abordagens ao compreender a política por trás dos documentos. Para tanto, estes serão considerados como instrumentos da ação pública, nos termos de Lascoumes e Le Galès $(2012 ;$ 2007). Estes autores procuraram responder a questão, subjacente a 
uma lacuna observada entre as perspectivas sociológica e politológica: políticas públicas são geradas por instituições consolidadas que perseguem seus interesses a longo do tempo ou por sistemas sociais autônomos que definem suas regras para a ação? Nesse sentido, Lascoumes e Le Galès $(2007$; 2012) reestruturaram o campo com uma perspectiva que considera simultaneamente atores e suas interações, instituições, práticas e a estrutura estatal. Essa perspectiva defende a relevância dos instrumentos políticos como um conjunto de regras e procedimentos que governam as interações e os comportamentos dos atores e organizações, portanto, estruturando as políticas. Nessa acepção, instrumentos não provêm de meras decisões técnicas, mas influenciam o comportamento dos atores e criam incerteza sobre os efeitos das relações de poder (Lascoumes \& Le Galès 2007).

\section{Produção e circulação de documentos: o processo administrativo}

${ }^{6}$ Para dimensionar o fenômeno, vale mencionar que essa variedade temática se reflete no volume de cerca 350 mil processos autuados anualmente. Em 2016, cerca de 1.400 .000 processos administrativos tramitavam em papel em 8.445 setores (entre gabinetes,

coordenadorias, departamentos e setores).

${ }^{7}$ De que são exemplos a Lei Municipal no 14.141/2006 e o Decreto Municipal $\mathrm{n}^{\circ}$ $54.714 / 2010$.

${ }^{8}$ Lei Federal no 12.527 , de 18

de novembro de 2011.
As práticas e os discursos burocráticos são produzidos e circulados por meio de uma grande variedade de documentos, o que levou autores inclusive a caracterizar burocracias como máquinas de produzir inscrições (Gupta 2012). Notas técnicas, memorandos, minutas, despachos, planos, requisições, relatórios, manuais, atas, circulares são alguns exemplos das variadas classes de documentos. Cada tipo possui uma lógica própria, que molda seu significado e uso. Neste trabalho, observamos especificamente um dos mais relevantes documentos para o funcionamento da burocracia: o processo administrativo.

No contexto da Prefeitura de São Paulo, o conjunto de ações necessárias à formalização de políticas e atividades administrativas se reflete na variedade de objetos dos processos. Contratações de serviço, aquisição de bens de consumo ou bens permanentes, nomeação de pessoas, transferência e exoneração de pessoal, elaboração legislativa, desdobro de lote, regularização fundiária e licenciamento edilício são alguns exemplos da variedade temática. Cada política reúne uma variedade desses processos, que transformam solicitações, motivações, fundamentações e decisões em ações concretas ${ }^{6}$.

Tipicamente, o processo administrativo se compõe por documentos que registram solicitações, ações e decisões relacionadas ao documento que lhe deu origem, tendo sua instrução normatizada em legislação geral e específica ${ }^{7}$. Uma das finalidades desse processo é permitir controle e responsabilização funcional, o que é frequentemente mencionado nos estudos sobre burocracias (Bresser-Pereira \& Grau 2006). Outra de suas finalidades é fornecer informações adequadas para a tomada de decisão das autoridades. Essa decisão, materializada em um despacho, traduz um interesse em ação estatal. Em ambos os casos, há registro de fatos e, a partir deste, o seu agenciamento pelos atores. Ademais, também são objeto de escrutínio público nos termos da Lei de Acesso à Informação ${ }^{8}$. Cidadãos e organizações que trabalham com a promoção da transparência parecem esperar que eles contenham o registro dos fatos tais como ocorreram. A própria manutenção da legitimidade estatal depende dessa crença de que são artefatos de registros neutros e armazenam informações (Hull 2012). Este artigo, justamente, problematiza o processo pelo qual os documentos são construídos.

Os processos administrativos são abertos por motivação da própria administração pública ou a partir de solicitações de pessoas físicas e entes externos. Em sua versão analógica, são formados por uma pasta de papel com capa protetora que reúne, cronologicamente, documentos, tais como requisições, memorandos, publicações e e-mails, com informações requeridas, obrigatórias e relevantes, produzidas ou não para seu fim. Sua produção é uma atividade coletiva, construída pela circulação por diversas unidades que a ele juntam novos documentos, complementando a história que nele se registra. Trata-se de uma 
${ }^{9}$ Dados de junho de 2017, obtidos por meio do Sistema de Gestão de Pessoas (Sigpec) da Prefeitura do Município de São Paulo. presença bastante marcante nas burocracias da camada intermediária (mesmo com o processo eletrônico, circulam processos legados pelas mesas), como mostra a Figura 1.

Dentre as atividades exercidas nos processos administrativos estão: 1) as manuais, que envolvem transporte, protocolo, autuação e junção de documentos (confecção de pastas, aplicação de carimbos de juntada e numeração de folhas); (2) administrativas, que envolvem registros de tramitação em sistema de controle, recepção, distribuição, preparação de encaminhamentos simples e coleta de assinaturas; (3) analíticas, como elaboração de pareceres, notas técnicas, análises de mérito, encaminhamentos politicamente sensíveis e despachos.

Cada atividade é fundamental para que os processos circulem, o que se evidencia pelo caso exposto na Introdução. Cada etapa também envolve um tipo diferente de burocrata. Nas atividades manuais e administrativas, há cerca de 23 mil burocratas de back-office em toda prefeitura (aproximadamente 20\% dos servidores ativos $)^{9}$. Para estes, os processos envolvem as obrigações de autuar, carimbar e numerar páginas, havendo pouco espaço para interferir em seu

Figura 1 - Processos administrativos em uma burocracia municipal

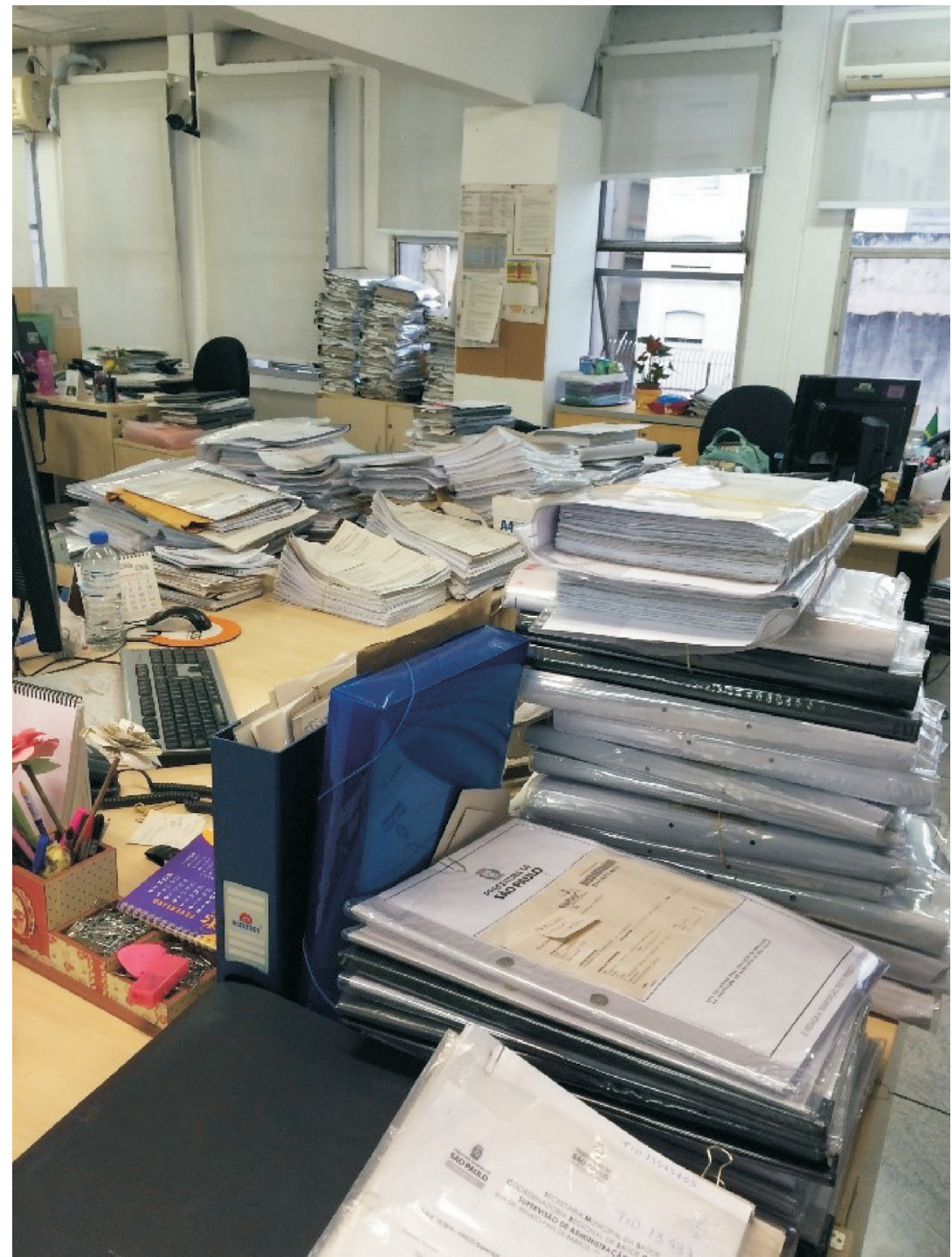

Fonte: Telma Hoyler. 
conteúdo. Ainda assim, há espaços para o exercício de discricionaridade tanto quanto ao tempo de realizar uma determinada atividade como nos procedimentos de junção e sequenciamento das informações inseridas no processo. Nesse sentido, a demora para a execução de uma tarefa pode inviabilizar a realização de uma ação pelo Estado e tornar o ato formal da decisão inócuo, e a junção desordenada de informações em um processo pode afetar a qualidade da informação do processo. A atividade analítica - com diferentes graus de dificuldade e eventual intersecção com as atividades administrativas - é desenvolvida por outra parcela desses burocratas, a de médio escalão, que totaliza em torno de 7.600 burocratas (cerca de 7\%), considerando-se chefias de setores e coordenadores.

Ao definir competências específicas de cada órgão da burocracia, a normatização de procedimentos técnicos e administrativos também indica quem possui competência legal para realizar determinadas atividades, como autorizar uma contratação ou elaborar um parecer técnico. Todo o trabalho nas burocracias está vinculado a processos, mas é a camada intermediária que lida diariamente com eles. Pudemos observar que a camada da burocracia que interage diretamente com a população e o alto escalão também se manifestam nos processos, mas suas principais atividades são, respectivamente, o atendimento à população nos guichês e a condução política dos órgãos. Em termos de processos de trabalho, os burocratas que interagem com a população recebem documentos e os encaminham aos burocratas do back-office, que abrem novos processos administrativos ou os juntam em processos já existentes. $\mathrm{O}$ alto escalão, por sua vez, formaliza sua manifestação assinando despachos preparados com o apoio de sua assessoria técnica e jurídica, cuja função é assegurar tanto a coerência dos processos administrativos quanto o devido embasamento da tomada de decisão nos processos administrativos.

A Lei Municipal $n^{\circ} 14.141 / 2006$ regulamenta o processo administrativo, prevendo diferentes níveis de formalização de documentos administrativos e estabelecendo uma separação entre os tipos comuns e tipos especiais, que possuem regulamentação específicas para protocolo, prazos etc. Ainda assim, no que não for coberto por essa dupla regulamentação, os processos administrativos comuns e especiais têm sua lógica regida pelo que se denomina, no direito, de princípio do formalismo moderado, que consiste na ideia de que suas normas devem garantir a segurança quanto ao cumprimento do direito, no que se refere ao princípio do contraditório e da ampla defesa. Ao mesmo tempo, sua forma não deve ser entendida como um fim em si mesmo (Medauar 2014). Assim, esse conjunto de regras não oferece um passo-a-passo para o trabalho, restando, aos burocratas, um conjunto de decisões cotidianas não só sobre $o$ que deve ser registrado, mas como deve sê-lo. Portanto, a incerteza ${ }^{10}$ no processo de elaboração dos documentos acompanha o desempenho, sobretudo das funções analíticas.

\section{Os riscos de quem produz documentos}

${ }^{10}$ Incerteza, conforme Taleb (2012) e Knight (1921), é uma condição ontológica do indivíduo. Risco, por sua vez, é uma condição que se vincula às decisões tomadas pelos indivíduos e às expectativas de seus efeitos no futuro. Desse modo, a incerteza é sempre presente e incontrolável, enquanto o risco é mensurável, podendo ser aumentado
O acompanhamento do cotidiano dos burocratas que manuseiam processos permitiu identificar um importante dilema relacionado à produção e circulação de documentos: ao mesmo tempo em que há obrigatoriedade do registro de ocorrências relacionadas a um determinado contrato, programa ou política nos autos de um processo, o ato de registro produz riscos relacionados diretamente ao conteúdo e a forma como esse registro é produzido.

No contexto das práticas burocráticas, o risco tem duas naturezas, uma administrativa e uma política. No primeiro caso, por exemplo, mesmo o burocrata que age de boa-fé sofre o risco de penalização, por negligência, imprudência ou imperícia, se assim for estabelecido por uma auditoria sobre 
reduzido ou, no limite, mitigado pela ação do indivíduo.
${ }^{11}$ Como os Tribunais de Contas, o Ministério Público e as Controladorias. processos nos quais ele foi responsável por algum ato, recomendação ou decisão, com decorrente sanção administrativa e até criminal. No segundo caso, trata-se do risco de dano à reputação individual ou de um grupo frente aos superiores ou burocratas da mesma camada. Por exemplo, impasses de ordem técnica e formal podem tanto impedir a condução de uma política nos termos definidos pelo alto escalão, como inviabilizando por completo a entrega de uma política. Isso levaria à perda de poder e de espaço, que se traduz, no caso dos burocratas em cargos de confiança, em remoção e até mesmo exoneração.

Este risco é amplificado pela dissociação entre os tempos da política (politics) e o tempo dos papéis, dissociação que frequentemente leva os burocratas a agir de uma maneira e registrar a ação de outra, ou mesmo a não efetuar registro algum.

Tempo dos papéis, conceituação emprestada de Nadai (2012), refere-se ao tempo de elaboração de documentos e à circulação típica dos processos pelos setores - incluindo elementos comportamentais e legais que o prolongam. Pela lógica dos papéis, uma manifestação ou parecer somente é produzido quando chega um pedido formal, via oficio ou processo que, por sua vez, frequentemente gera uma obrigação de manifestação formal.

Não é difícil entender, por essa lógica, que medicamentos não sejam comprados pelo Estado até que o departamento competente pela licitação receba um documento de requisição. Há, aqui, um rito a ser cumprido, uma hierarquia formal a ser respeitada. Como a regulamentação dos atos administrativos e os princípios que norteiam a atuação do Estado estabelecem a necessidade de que toda a ação seja adequadamente motivada, planejada e tempestiva, e o fato de que as fiscalizações e auditorias realizadas pelos órgãos de controle têm como parte de suas atividades a revisão da instrução, os processos devem ser sempre formalmente coerentes, seguindo uma ordem cronológica do começo ao fim. Entretanto, esse tempo, por vezes demasiado longo, frequentemente entra em choque com as expectativas quanto ao andamento e aos resultados, como demandas advindas do alto escalão, afetando, inclusive, o timing das políticas públicas. A afirmação quanto à existência de um tempo dos papéis não significa que este não esteja permeado por um tipo de política - que se expressa, por exemplo, na escolha de um procurador mais inclinado a uma determinada posição jurídica, para que elabore um parecer jurídico favorável, ou na apresentação de impedimentos legais para dificultar a tomada de decisão sobre um processo sobre o qual se é contrário. Essas decisões influenciam o tempo de circulação de um processo, mas este tempo é regido pela lógica da formalidade.

O tempo da política, por sua vez, é regido pelas entregas de políticas e pelas negociações de um governo eleito. Para atender às suas necessidades, muitas vezes atividades importantes são realizadas antes de qualquer formalização dos atos que deveriam, de acordo com as regras, tê-las originado. A isso se sucede, posteriormente, o esforço do devido registro, contando-se uma história que frequentemente omite a real trajetória percorrida pelos burocratas. Pressionados por seus superiores para acelerar as entregas de política pública e com as atenções primariamente voltadas aos aspectos não-formais de sua implantação, não raro os burocratas relegam a instrução processual ao segundo plano. Com isso, aumentam o risco de que ela seja feita de maneira desarticulada, com prejuízo para a coerência lógica dos processos e aumento do risco de erros formais e consequentes questionamentos e sanções advindos dos órgãos de controle.

Com o crescimento da atuação dos órgãos de controle ${ }^{11}$ (Arantes et al., 2010), fenômeno que não foi acompanhado na mesma proporção do fortalecimento das estruturas e capacidades técnico-administrativas, o risco se mostra grande, e a incerteza, justificada. Para evitar a interrupção da execução 
de atividades, as exigências de tais órgãos constituem um desafio duplo aos burocratas: garantir que as decisões tomadas sempre são as melhores possíveis e que a condução dos processos, produzidos em contextos muitas vezes marcados pela precariedade administrativa e pelas turbulências do processo político, deu-se na melhor forma do Direito, com a devida documentação, fundamentação e tempestividade. Assim, "documentar devidamente" constitui a principal parte do trabalho da camada intermediária das burocracias.

Em função do dilema do registro e da dissociação dos tempos, o comportamento dos burocratas em relação ao processo está ligado, em grande medida, à avaliação que fazem do risco, de modo que a materialização do processo administrativo é resultado de um conjunto de táticas empreendidas pelos burocratas para reduzir riscos. Pode ser também o fruto da incapacidade de reduzi-los ou, no caso de conflitos intra e interburocráticos, de uma opção deliberada de aumentar os riscos para uma burocracia ou burocrata rival. De todo modo, é a partir desse dilema que burocratas e documentos se relacionam e as políticas acabam sendo produzidas.

Se, por um lado, a atividade de instrução de processos conta com a regulamentação em leis, decretos, portarias etc., por outro ela é profundamente afetada pela contingência. Como colocam Huising e Silbey (2011), os burocratas de médio escalão governam o gap existente entre as regras e a possibilidade real de aplicação. Para tanto, exercem diferentes tipos de práticas de governança de gap que permitam adaptar as regras gerais aos contextos específicos. Nesse sentido, argumentamos que os documentos são elementos importantes na redução desse gap, salvaguardando a execução de políticas com redução do risco funcional e político ao transformar o conjunto de ações e afirmações individuais em uma narrativa coerente e fundamentada por documentos que, uma vez formalizados, ganham força real.

A título de exemplo, veja-se um caso que envolve o recrutamento de pessoas no governo municipal. O governo municipal apresentou propostas de criação de concursos para novas carreiras e para preencher carreiras já existentes, no que totalizaria cinco concursos públicos. A negociação com a Câmara Municipal, para aprovação das propostas, tomou os primeiros anos do governo. Como era de interesse do governo que os concursos fossem realizados e os quadros convocados ainda durante a gestão, dele partiu a orientação à burocracia para que fossem realizados em oito meses o que normalmente demoraria dois anos.

Para ilustrar o que significa, na linguagem dos papéis, realizar um concurso, listamos abaixo um subconjunto das atividades e documentos envolvidos na instrução de um processo administrativo de concurso público:

1) Redigir requerimentos para justificar um novo concurso;

2) Abrir um processo administrativo;

3) Elaborar e juntar ao processo um conjunto de estudos jurídicos, de impacto orçamentário e financeiro sobre a folha de pagamento;

4) Solicitar autorização para contratar uma empresa responsável pela realização do concurso;

5) Elaborar o edital de contratação;

6) Analisar a documentação das empresas concorrentes;

7) Constituir uma comissão avaliadora.

Quase todas essas atividades são entremeadas por registros de atas, solicitações de publicações (antes mesmo da definição de conteúdo programático), preparação de relatórios de acompanhamento das atividades da empresa contra- 
tada para realizar o concurso, provas, homologação do concurso, cursos de formação e autorização para a nomeação.

Para cumprir a orientação dada pelo governo, conforme avançavam as negociações com a Câmara, a equipe responsável por realizar o concurso iniciou a instrução do processo. Inicialmente, a equipe criou apenas um único processo administrativo para todos os concursos, motivada pela ideia de que isso reduziria o tempo de circulação entre os diversos departamentos envolvidos na elaboração da extensa lista de documentos necessários. Contudo, a tramitação de uma parte dos projetos de lei foi barrada na Câmara durante as negociações (uma contingência do tempo da política) e, uma vez que a requisição que deu origem ao processo dos concursos era única, todos teriam de ser paralisados, o que poderia impactar severamente a política de recrutamento. Isso acendeu o alerta da equipe responsável pelos concursos, que identificou que a paralisação de todos os concursos também poderia ocorrer na fase de sua realização, caso houvesse questionamento pelos órgãos de controle ou por candidatos dos concursos em ações judiciais.

A partir disso, o alto escalão decidiu desmembrar os concursos em diferentes processos administrativos. Para a burocracia intermediária, isso significava não apenas alterar os rumos da instrução processual, mas produzir uma justificativa que desse coerência a essa decisão sem utilizar como justificativa o risco político, que não configura motivação adequada para uma decisão de cunho administrativo. Em termos materiais, foram abertas novas pastas de processos administrativos, com cópias dos documentos que constavam no processo inicial, e a estas foram juntados ofícios e termos de esclarecimento para construir uma narrativa coerente para o fato, o que não foi realizado por completo.

Em um segundo momento, durante a fase de realização dos concursos, a apresentação de pedidos de vista dos processos por candidatos (o que expressa uma contingência do tempo da política) produziu uma nova urgência de "resolver" a junção adequada de documentos e a narrativa coerente que justificasse a separação dos concursos em processos individuais. Como essa urgência não condizia com o tempo dos papéis e com o conhecimento e as práticas prévias da burocracia de recrutamento de pessoas, foram cometidos erros formais de numeração e duplicação. Isso obrigou a equipe a rapidamente identificar todos os erros e elaborar soluções de correção com justificativas coerentes em um contexto de alto risco de que uma interferência dos órgãos de controle ou da Justiça prejudicasse seriamente os planos do governo de realizar o concurso ${ }^{12}$, evitando-se a drástica "solução" de arrancar e substituir páginas com assinaturas. Caso removesse páginas, além de estar cometendo uma irregularidade, isso obrigaria uma nova e demorada tramitação dos processos entre as burocracias que já haviam previamente se manifestado no processo inicial para que se manifestassem nos processos. Abaixo, destacam-se trechos desses documentos:

"Foram desentranhadas as folhas 172 a 231, que em razão de pertinência temática retornaram ao processo administrativo num. 2050.0.133.148-9".

"No decorrer da elaboração do mencionado certame a Administração decidiu pela continuidade da tramitação administrativa de maneira fracionada, razão pela qual este processo foi individualizado e autuado a partir do desentranhamento das folhas 182 a 205 do processo 2009-0.145.259-3, que passam a constar no Processo 3019-0.189.-143-0 sob a numeração de folhas de 2-40, que já eram originariamente deste processo".

Esse caso ilustra não só as dificuldades e soluções informais para os problemas encontrados pelos burocratas, mas evidencia o esforço da burocracia em construir uma narrativa formal que seja coerente do começo ao fim, já que qualquer problema no rito processual pode ocasionar em paralisação da política 
${ }^{13}$ Inicialmente, isso produziu redução no ritmo de trabalho até que um novo ritmo fosse tacitamente negociado. e, em última instância, a responsabilização funcional. O gap entre o interesse em implementação da política e a contingência foi resolvido justamente pela forma do registro nos documentos.

É importante destacar que o discurso burocrático escrito revelado nesse caso particular é marcado pela utilização de verbos na voz passiva, substantivos que se referem a conceitos abstratos, como "Administração", e pela constante referência a normativos e decisões anteriores, tornando o texto um contínuo apanhado de referências a documentos e entidades externas, como observou Hull (2008) em sua análise sobre as práticas da burocracia paquistanesa. Para o autor, a organização burocrática é uma forma social desenhada para a ação coletiva. Contudo, o mecanismo pelo qual se busca produzir a ação social é precisamente pela individualização da ação, expressa nas manifestações individuais de burocratas, em grau não conhecido por outra organização social. No entanto, ao contrário do que se esperaria, o resultado que se observa é a contínua coletivização das responsabilidades por meio de uma linguagem cifrada que busca evitar, efetivamente, essa individualização. Assim, o aumento da documentação de procedimentos não se traduz automaticamente em garantia de accountability ou de transparência das ações da burocracia. Ao produzir mais documentação, as burocracias podem estar produzindo seu contrário: mais opacidade.

O caso acima também reflete outra estratégia de diminuição do risco posto pela dissociação dos tempos da política e dos papéis: a interferência sobre o ritmo dos papéis.

Para acelerar a realização dos concursos, o alto escalão orientou que a tramitação dos processos fosse unificada e designou um assessor do gabinete para acompanhá-la pessoalmente. $\mathrm{O}$ assessor não precisaria se manifestar nos processos, apenas orquestrar seus ritmos. Ou seja, imputaria o tempo da política no tempo dos papéis e regeria o processo sem se preocupar com o risco administrativo, por não estar submetido à condição que caracteriza o risco, embora os demais burocratas (back-office e médio escalão) ainda estivessem ${ }^{13}$.

Percebemos que a disponibilidade de estratégias para minimizar os riscos envolvidos na condução de processos varia conforme o posicionamento dos atores na estrutura burocrática, o que lhes confere acesso a tipos distintos de informação, bem como ao espaço discricionário de determinar procedimentos; e o circuito de relações formais e informais. O tecido relacional pode ser influenciado pela posição hierárquica, mas apenas a primeira condição não garante informação e tampouco a possibilidade de se negociar os termos de construção do fato narrado nos processos administrativos e nos próprios documentos. Isso destaca a importante contribuição de Crozier (1977) aos estudos organizacionais e burocráticos - e que influenciou a sociologia de guichê - para quem a incerteza é um recurso fundamental de negociação para a ação coletiva, embora seja desigualmente distribuída entre os atores.

A necessidade de se alistar do maior número possível de burocratas envolvidos no conjunto das atividades para a elaboração de uma narrativa coerente sobre os fatos em um processo nos permite compreender os documentos como uma forma de organização das relações entre os burocratas no governo que estabiliza a ação coletiva e torna mais previsível o comportamento dos atores.

Evidências para esta afirmação foram colhidas em campo durante as atividades de mapeamento dos procedimentos administrativos para promover a transição ao sistema totalmente eletrônico. Num caso observado, uma secretaria tinha interesse em prosseguir com um procedimento administrativo ao qual se opunha o chefe do setor jurídico, responsável pelas designações de procuradores na elaboração de pareceres jurídicos. Sem condições objetivas para 
removê-lo ou substituí-lo, o processo foi interrompido em sua tramitação até que ele entrasse em férias, o que permitiu ao gabinete negociar com seu substituto um encaminhamento favorável, ao mesmo tempo em que garantia ao chefe regular que não seria responsabilizado pela decisão. Assim, os burocratas privilegiaram um itinerário que era favorável à confirmação de uma decisão incluída no processo. Ainda que passem pelos mesmos departamentos e unidades, diferentes atores configuram caminhos distintos, escolhidos, sempre que possível, em função das relações entre os burocratas e de suas diferentes estratégias de operar o gap entre o que a lei manda fazer e as possibilidades objetivas.

Em que pese esta evidência particular, não são todos os burocratas que conseguem construir alianças com os demais a fim de garantir a confirmação de um fato que está sendo construído em um processo administrativo. A transformação de uma afirmação (despacho ou encaminhamento isolado) em fato (encadeamento coerente de folhas de informação, documentos comprobatórios e despachos em um processo administrativo) durante os processos de políticas públicas envolve custos e, por isso, é de se esperar que essa possibilidade varie conforme o posicionamentos dos atores em cada burocracia, distinções ainda a serem pesquisadas.

Quando a avaliação é de impossibilidade de se produzir uma narrativa coerente e os riscos são altos, os burocratas recorrem até mesmo ao expediente da devolução de processos à unidade que o encaminhou, com a alegação de que houve engano na tramitação, sem que se tenha de assumir o risco de neles se manifestar.

Nesse sentido, ouvimos relatos de processos que, após serem encaminhados a uma unidade que, no entendimento do remetente, deveria se manifestar sobre determinada matéria, foi devolvido - não sem a inclusão de nova folha de informação com cabeçalho, brasão da Secretaria, número e nome do processo, endereçamento e vocativo, assinatura e carimbos - com uma única frase de relevo: "aqui por engano". E, assim, o processo retornava para uma nova rodada de decisões, podendo, no limite, ter sua tramitação interrompida até nova oportunidade ou pressão política.

Enquanto essa prática se assenta na complexidade de casos e na variabilidade de interpretações que os burocratas podem ter sobre uma determinada questão, em outros casos observa-se simplesmente o descumprimento explícito das regras do processo administrativo, com práticas como a remoção de páginas de processos - por exemplo, para corrigir informações equivocadas a posteriori, ocultar informações sensíveis ou comprometedoras, dificultar o acesso de outros atores com opiniões e interesses divergentes ao teor do processo, alongar prazos de resposta, etc. - ou mesmo pelo "esquecimento" do processo em gavetas e armários.

\section{Os efeitos dos documentos nas práticas do Estado}

Até aqui, vimos que os burocratas da camada intermediária têm os processos administrativos como principal instrumento de sua atuação, que os documentos foram criados para registrar a realidade do que acontece no Estado e que a obrigatoriedade do registro coloca um dilema, face aos riscos administrativos e políticos, em função justamente do quê e de como se registram informações nos processo. Os burocratas buscam reduzi-los a partir de um conjunto de estratégias como a elaboração de registros vagos e genéricos, o alistamento de outros burocratas para a construção de narrativas coerentes, a omissão de registros e mesmo a adulteração e eliminação documentos.

Mas há um conjunto de características derivadas dos próprios documentos de suas características inerentes e do contexto institucional que os normatiza - 
que produzem efeitos relevantes sobre a atuação dos burocratas. Por serem pontos obrigatórios de passagem, os burocratas atuarão sobre os documentos de modo a mitigar riscos, com isso afetando as condições de produção das políticas. A partir de três casos, esta seção apresenta os efeitos que os documentos produzem, expondo seus efeitos sobre a avaliação de risco dos burocratas e seu impacto na política e na implementação de políticas. Os nomes de cada subseção expressam as propriedades dos documentos e seus efeito sobre as políticas.

\section{V.1. Produção da verdade e constrangimento à tomada de decisão}

A tomada de decisão é sempre constrangida pelo que consta nos autos. Não é possível decidir sobre algo que necessita de uma formalização em processo administrativo se esta decisão não estiver amparada pelo próprio processo. Nesse sentido, Gupta (2012) afirma que o que está registrado em um processo ou o que está faltando nele - exerce uma influência muito maior no processo de tomada de decisão do que as ideias da pessoa tomando a decisão. Isso não é apenas uma premissa jurídica, mas precisa ser trazida à tona pelo impacto sobre as políticas.

Tome-se como exemplo um caso decorrente da fiscalização de um contrato de serviços, em que é necessário avaliar a aplicação de penalidades em função de descumprimento contratual. Para que um prestador de serviço seja penalizado por descumprimento total ou parcial dos termos de um contrato, com implicações que possam vir a inviabilizar sua contratação futura, é preciso que o fiscal do contrato registre devidamente o ocorrido, mencionando o descumprimento de qualquer cláusula. Esse ato desencadeia uma série de procedimentos administrativos, abre prazos de defesa pela contratada e de respostas pela administração pública, que pode ou não culminar em aplicação final das penalidades. Ocorre que os fiscais de contrato frequentemente são burocratas designados para acompanhar a prestação de serviços enquanto acumulam outras funções, e, ainda que haja uma recente política de regulamentação e treinamento para a função, ela ainda não é prática corrente. A designação dos fiscais pelas chefias imediatas ou pelo gabinete de cada secretaria é feita com base em critérios de lealdade política e/ou baixa percepção do risco funcional pelo burocrata. Em ambos os casos, face às limitações impostas pela assimetria de poder, raros são os casos em que o fiscal é um burocrata bem posicionado na burocracia, informado e ainda resistente a possíveis assédios morais.

Se um fiscal de contrato registra uma ocorrência de inconformidade na prestação de um serviço, mas o alto escalão, por motivos variados, decide não

${ }^{14}$ Registra-se que isso não necessariamente implica assumir uma postura leniente com o prestador, mas também decorre de uma avaliação de que o risco de se conduzir um litígio para a sanção de um prestador pode trazer mais prejuízos à execução de uma política do que os problemas que ocasionaram o descumprimento inicial, opondo riscos políticos e administrativos. penalizar a empresa ${ }^{14}$, a presença de tal informação no processo pode levar à responsabilização do próprio fiscal pela não penalização, caso esse processo passe por uma avaliação dos órgãos de controle. Afinal, a decisão de não penalização da empresa face ao registro de descumprimento contratual é uma irregularidade.

Em contrapartida, caso ocorra algum incidente com grandes repercussões políticas e administrativas nesse contrato, a ausência do registro de inconformidades pode levar este fiscal, a depender de investigações posteriores, a ser acusado de omissão ou negligência, ainda que o fiscal possa alegar não ter identificado irregularidades por omissão ou ocultação de evidências da própria prestadora de serviços. Como problemas graves e de repercussão política são raros em relação ao montante de contratos e eventos de fiscalização contratual, e como a responsabilidade no primeiro caso é muito mais facilmente identificável, dado que o fiscal registrou as informações no processo, ocorre, com frequência, que descumprimentos contratuais não são registrados no decorrer da execução. 
Como consequência, frequentemente, licitações são vencidas por prestadores de serviço que descumpriram seguidamente cláusulas contratuais previstas, pois a administração não dispõe dos registros dos fiscais que fundamentariam desabilitar uma empresa em função de problemas prévios. O documento em que consta o "não registro de inconformidade", posto que opera como um ponto de passagem obrigatória (Callon 1986), retorna como fato, e na ausência de registros sobre irregularidade na execução do serviço, não se pode construir objeções a contratações futuras, impondo-se prejuízo à implementação de políticas.

Vale mencionar que a ausência desses registros foi apontada por diversos burocratas como um dos motivos que permitiu a recontratação de uma empresa responsável por um dos principais serviços terceirizados da prefeitura, não obstante frequentes os relatos de irregularidades graves ao longo de toda sua operação, prejudicando a implementação de uma nova política que estava sendo desenhada.

O dilema do registro pelo risco de responsabilidade funcional explica uma parte importante da questão. A falta de registro também pode ser explicada pela dificuldade em operacionalizar a penalização contratual sem risco de prejuízos na oferta dos serviços contratados, por eventuais interesses eleitorais de financiamento de campanha e por corrupção.

Seja qual for o caso, a operacionalização desses interesses passa pela decisão sobre o registro. O "fato" registrado volta como verdade e futuras contratações necessárias à execução de políticas podem ser prejudicadas. Isso remete ao apontamento de Lascoummes e Le Galès (2012) a respeito de como documentos podem significar um filtro às oposições políticas e criar uma aparência de consenso onde há contradições. Pudemos observar que os burocratas lidam cotidianamente com esse efeito na construção de políticas públicas.

\section{V.2. Descolamento contextual e efeito inercial}

A situação aqui descrita é bastante relacionada à anterior - em que um registro feito no passado interfere na tomada de decisão. Nesse caso, no entanto, não se trata de um constrangimento, e sim de uma opção deliberada em descolar precedentes de seu contexto original dando uma vida própria aos papéis, com isso produzindo um efeito inercial à semelhança do que foi apontado teoricamente por Lascoumes e Le Galès (2012).

No caso do fracionamento do processo administrativo referente aos concursos acima mencionados, para reduzir a necessidade de novas tramitações entre as secretarias que deveriam legalmente se manifestar no processo, bem como de uma nova rodada de negociações sobre os termos dessa narrativa, a burocracia responsável pelo processo incluiu, em todos os novos processos, uma cópia da mesma justificativa sobre a forma de contratação defendida pela Procuradoria Geral. Tratava-se de um parecer jurídico cuja data de produção era superior a duas décadas. Nas discussões sobre como proceder com a justificativa, um assessor do gabinete da secretaria responsável pelos concursos indagou se esse documento ainda seria pertinente, e se não seria o caso de aproveitar a oportunidade da separação dos processos e o perfil distinto das carreiras então sendo criadas, para se aprimorar os critérios de seleção da empresa responsável pelo concurso. Com isso, ele alegou que seria possível melhorar a política de recrutamento na prefeitura, estabelecendo, nos editais de seleção da empresa responsável pela condução do concurso, novos critérios para melhorar o recrutamento de burocratas. Mal terminara seu argumento, foi interpelado pelo burocrata responsável pela instrução processual, cuja resposta pôs fim à discus- 
são e trouxe empecilho à mudança: "sempre fizemos assim e ninguém questionou".

Nesse sentido, seguimos Vianna (2014) ao considerar que os documentos constroem a realidade tanto ao terem efeito sobre determinada situação da qual fazem parte, como por aquilo que sedimentam no tempo. É à documentação que recorrem os burocratas quando devem realizar um procedimento novo ou quando ninguém sabe o que fazer em uma situação complexa. Não nos referimos somente à documentação juntada ao processo, mas a uma documentação anterior, precedentes administrativos que registram como eventos de natureza similar foram tratados no passado. Se as soluções legais e administrativas já foram oferecidas em algum momento e referendadas em outros processos, há uma forte inclinação a repeti-las, ainda que não seja a decisão percebida pelos burocratas como ideal.

A evocação a casos e processos anteriores na elaboração de justificativas para a ação no presente transporta narrativas, discursos e crenças sobre legalidade e legitimidade depositadas sobre o documento no passado, acabando por produzir um descolamento entre o contexto específico que gerou uma solução e a solução em si.O documento assume então uma espécie de legitimidade em si, ganhando força de verdade e sendo agenciado pelos burocratas a partir dessa propriedade. Nesse sentido, é possível estender aos documentos o argumento de Desrosières (1993) a respeito das estatísticas, as quais estruturam o espaço público impondo categorizações e criando pré-formatações de debates que se tornam, frequentemente, difíceis de ser questionadas. Uma vez que esse agenciamento de documentos reduz o risco de responsabilidade funcional ao vincular novas ações a ações precedentes que, por sua vez, já superaram os ciclos da fiscalização, o agenciamento é mobilizado sucessivamente pelos burocratas e, assim, a legalidade - entendida aqui apenas como coerência interna de um processo administrativo - é fabricada.

À semelhança do que foi identificado por Vianna (2014) nos documentos de guarda de menores pela Justiça da Infância, observa-se um processo de construção de uma autonomia relativa dos processos, cuja força de verdade é reforçada pela repetição. Os documentos ganham, assim, um "efeito autoridade": tornam-se recursos mobilizados ou desmobilizados de maneira autônoma em relação aos agentes e contextos em que foram produzidos, mas formando a ação coletiva do Estado. E, por ser ação coletiva do Estado, reduz também o risco individual dos burocratas (Hull 2012).

Em que pese a relevância dos efeitos autoridade e inércia dos documentos e de seu agenciamento pelos atores, nem sempre a adoção dos instrumentos é deliberadamente estratégica, como sugere a teoria da instrumentação da ação pública. Pode ser também a consequência de uma sucessão de eventos não intencionais que precisam também ser investigados, como colocam Menon e Sedelmeier (2010).

\section{V.3. (Não) comprovação da negociação e governabilidade}

Diferentemente das situações anteriores, na situação apresentada a seguir não observamos o constrangimento a uma situação presente em função do que que foi registrado nos papéis no passado, mas uma negociação deliberada para evitar que tal cenário chegasse a se configurar. Ou seja, mesmo que uma negociação tenha produzido papéis, as condições de governabilidade dependeriam de sua ocultação. Outra diferença fundamental é que, neste caso, cada documento registra individualmente uma negociação política, de modo que um descolamento contextual com efeito inércia não seria possível. 
Tome-se um caso hipotético de uma negociação entre um vereador e um burocrata de alto escalão, versando o empenho de um recurso financeiro (emenda parlamentar) para a realização de um projeto que traria benefícios para a constituency do vereador. Dessa negociação, a burocracia produz um documento que serve de comprovação, para o vereador, dos esforços que empreendeu para garantir os benefícios requisitados por sua constituency, com efeitos sobre o prestígio que o vereador tem junto a ela, ainda que o acordo não seja levado adiante. Caso isso ocorra, pode o vereador alegar ter feito aquilo que estava em sua competência, transferindo o custo político para o outro polo da negociação.

O documento, em muitos casos, tem função de intermediário na costura do acordo. É a partir da crença de que os documentos registram fatos verdadeiros que os agentes passam a atuar para atingir seus objetivos. Essa análise decorre da observação contínua da atuação dos burocratas na condução do projeto enunciado na introdução. A mudança do meio de produção e circulação de informação do analógico para o digital trouxe à tona a função mediadora dos documentos na produção de opacidade e sua íntima relação com a governabilidade. Relatamos, a seguir, um breve caso ilustrativo, que envolve os procedimentos de nomeação de servidores em cargos de livre provimento, também denominados "comissionados".

O procedimento de nomeação de comissionados inicia-se com uma solicitação da secretaria requerente, encaminhada a um conselho consultiva do alto escalão que, por sua vez, avalia a regularidade da nomeação em recomendação dirigida ao prefeito ou secretário com base em critérios como a existência de vínculos familiares com pessoas do governo, entre outros elementos. Por fim, a autoridade competente delibera sobre a nomeação. Este é o processo formal, conhecido e esperado pelas partes.

De perto, porém, observa-se a operação de outras lógicas. Por exemplo, há um burocrata da secretaria responsável pela articulação política que, antes de cada reunião, elabora uma prévia da ata de reunião do conselho, segurando a tramitação das eventuais solicitações de nomeações feitas por políticos da base aliada, mas que não correspondem aos critérios exigidos para o cargo ou de quem o governo está esperando maiores contrapartidas. A vantagem disso é que o documento pode ficar parado em cima de alguma mesa sem que o prefeito ou secretário de governo se desgaste politicamente negando a nomeação, ao mesmo tempo em que o governo obtém crédito em eventuais negociações, podendo afirmar que já encaminhou o pedido ao conselho.

Assim, um processo de nomeação pode ter sua tramitação interrompida, aguardando o resultado de uma votação importante na Câmara Municipal cujo resultado fora previamente vinculado à decisão de nomeação, e que pode, por fim, ser efetivada ou arquivada. Enquanto isso era feito no papel, o controle sobre a materialidade diminuía os riscos que os burocratas responsáveis pela política enfrentavam e permitia que essa prática política funcionasse. A proposta de circulação eletrônica de documentos implicou, entre outras coisas, a concessão de maior controle da área demandante sobre os processos que ela mesmo inicia, podendo, por exemplo, acompanhar cada etapa de tramitação e identificar, a qualquer momento, o responsável pelo processo. Ainda que algumas sugestões de alteração de procedimentos no sistema tenham sido apresentadas e discutidas durante a negociação para a mudança na forma da circulação dos documentos, os alegados riscos de aumento das pressões diretas sobre os burocratas, intensificadas pelo meio digital ${ }^{15}$, inviabilizou a migração para o meio digital, tendo, como resultado, a prevalência da manutenção de práticas de trabalho que protegiam a dinâmica da governabilidade. Se a migração tivesse ocorrido, provavelmente as formas de circulação de documentos 
exatamente com quem se encontravam, impedindo que a secretaria pudesse proteger os servidores do setor com a despersonalização de responsabilidades. teria alterado as práticas. Os burocratas teriam que buscar outras formas de proceder com as nomeações.

Quando um documento é produzido para operacionalizar uma negociação política, também é produzida uma dependência relativa dos atores em relação a este, de maneira que ignorá-lo, derivar opacidade de seus termos (dificultando a compreensão de uma decisão) ou acelerar sua circulação afetam a governabilidade - condição de estabilidade em que o Executivo pode exercer suas funções e implementar políticas públicas.

\section{Conclusões}

Este estudo procurou evidenciar a importância dos documentos para a dinâmica organizacional da camada intermediária das burocracias - médio escalão e back-office - e seus efeitos sobre políticas e sobre a política. Tal importância se assenta no conjunto de regras que estabelecem a obrigatoriedade do registro e no controle disciplinar sobre os burocratas, que tornam os documentos pontos obrigatórios de passagem, assim como no agenciamento que os burocratas fazem deles, de modo a lidar com o dilema do devido registro a que estão submetidos. O resultado disso é que os burocratas da camada intermediária empreendem diversas estratégias para mitigar os riscos, que passam por utilizar a voz passiva e explicações genéricas nos documentos, evitar se manifestar, formar coalizões entre burocratas e até atribuir aos documentos propriedades que lhes permitem se resguardar: produção da verdade, descolamento contextual e (não) comprovação de negociações. Tudo isso finda por influenciar a política e as políticas, com efeitos sobre a tomada de decisão, a capacidade de se promover mudanças em políticas e sobre a garantia de governabilidade.

Dessa prática resulta uma primeira implicação aos estudos de política(s): essa dinâmica explica parte da tendência inercial das burocracias em relação às políticas públicas, com grandes incentivos a seguir caminhos seguros traçados anteriormente. A inovação em políticas públicas requer amplos processos de negociação, alinhamento, construção de verdades documentais, sendo necessários maiores estudos para compreendermos como ela ocorre, levando-se em consideração as práticas de registro documental.

Uma segunda implicação considera a importância do aspecto material dos documentos e diz respeito ao conteúdo da informação produzida pelo Estado, dada a influência que a incerteza quanto à pertinência e ao conteúdo dos registros imprimem nos processos e, portanto, na informação que o Estado, enquanto agente coletivo, produz sobre si mesmo. Ao contrário de outras interpretações correntes sobre documentação, e conforme aponta Scott (1998), as práticas de documentação não produzem necessariamente condições para o controle, seja das próprias burocracias sobre si mesmas, seja o controle feito por organizações da sociedade civil, podendo, inclusive, aumentar a opacidade do Estado.

Por fim, a vida política dos documentos implica a urgência de articular tal referencial com as teorias sobre criação de capacidades burocráticas e de coordenação (Gomide \& Pires 2014; Bichir 2016; Pereira 2014). Se entendermos o Estado em ação a partir da atuação individual de seus agentes e do entrelaçamento de redes pessoais que se desagregam e reagregam de acordo com interesses, compromissos, percepções, adesões e sentimentos, não redutíveis às fronteiras institucional-doutrinárias legalmente prescritas, como postulam Castilho, Lima \& Teixeira (2014), e ainda a partir de como a materialidade do Estado pode influenciar tais relações, a tarefa de compreender os desafios da direção política se complexifica. 
Este estudo é um esforço inicial de abertura dessa agenda de pesquisa. Mais estudos precisam ser produzidos para se compreender a estrutura de relações e de acesso a informações dos burocratas, os efeitos que produz sobre as práticas de documentação e, ainda, como documentos se combinam com outros instrumentos na produção de políticas públicas.

ITelma Hoyler (telmahoyler@gmail.com) é Doutoranda em Ciência Política pela Universidade de São Paulo (USP) e Pesquisadora Junior do Centro de Estudos da Metrópole da mesma universidade. Vínculo Institucional: Programa de Pós-Graduação em Ciência Política, Universidade de São Paulo, USP, São Paulo, SP, Brasil.

IIPedro Campos (ph.lopescampos@gmail.com) é Mestre em Administração Pública e Governo na Fundação Getulio Vargas (FGV) e Pesquisador do Centro de Estudos em Administração Pública e Governo da mesma instituição. Vínculo Institucional: Programa de Mestrado e Doutorado em Administração Pública e Governo da Fundação Getúlio Vargas, FGV, São Paulo, SP, Brasil.

\section{Referências}

Abrucio, F.L., 2007. Trajetória recente da gestão pública brasileira: um balanço crítico e a renovação da agenda de reformas. Revista de Administração Pública, 41, n. especial, pp. 67-86. DOI: 10.1590/S0034-76122007000700005.

Abrucio, F.; Pedroti, P. \& Pó, M., 2010. A formação da burocracia brasileira: a trajetória e o significado das reformas administrativas. In M. Loureiro; F. Abrucio \& R. Pacheco, eds. Burocracia e política no Brasil. Rio de Janeiro: FGV.

Abrucio, F.; Loureiro, M. \& Rosa, C., 1998. Radiografia da alta burocracia federal brasileira: o caso do Ministério da Fazenda. Revista do Serviço Público, 49(4), pp.47-82.

Akrich, M.; Callon, M. \& Latour, B., 1988. A quoi tient le succès des innovations? 1: L'art de l'intéressement. Gérer et Comprendre, 11, pp.4-17.

Appadurai, A., 1986. Introduction: Commodities and the politics of value. In A. Appadurai, ed. The Social Life of Things: Commodities in cultural perspective. Cambridge: Cambridge University Press.

Arantes, R.B.; Loureiro, M.R.; Couto, C. \& Teixeira, M.A.C., 2010. Controles democráticos sobre a administração pública no Brasil: Legislativo, Tribunais de Contas, Judiciário e Ministério Público. In M. Loureiro; F. Abrucio, F. \& R. Pacheco, eds. Burocracia e política no Brasil. Rio de Janeiro: FGV.

Azevedo, C. \& Loureiro, M., 2003. Carreiras públicas em uma ordem democrática: entre os modelos burocrático e gerencial. Revista do Serviço Público, 54(1), pp.45-59.

Bichir, R., 2016. Novas agendas, novos desafios. Reflexões sobre as relações entre transferência de renda e assistência social no Brasil. Novos Estudos, 35(104), pp.111-136. DOI: 10.25091/s0101-3300201600010006

Bresser-Pereira, L.C. \& Grau, N.C., eds. 2006. Responsabilização na administração pública (coletânea). São Paulo: CLAD/FUNDAP.

Buchanan, J.M. \& Tullock, G., 1962. The Calculus of Consent. Ann Arbor: Michigan University Press.

Campos, M., 2018. Public Policy Instruments and Their Impact: From analogue to electronic government in the Bus Services of São Paulo. Brazilian Political Science Review, 12(1), pp.1-26. DOI: 10.1590/1981-3821201800010003

Callon, M., 1986. Some Elements of a Sociology of Translation: Domestication of the Scallops and the Fishermen of St Brieuc Bay. In J. Law, ed. Power, Action and Belief: A New Sociology of Knowledge. London: Routledge \& Kegan Paul.

Castilho, S.; Lima, A. \& Teixeira, C., 2014. Introdução. In S. Castilho; A. Lima \& C. Teixeira, eds. Antropologia das práticas de poder. Rio de Janeiro: Contracapa.

Crozier, M., 1977. L'acteur et le système. Paris: Éditions du Seuil.

D’Araújo, C. \& Lameirão, C., 2011. Dirigentes públicos federais de alto escalão no governo Lula. In Cardoso; J.C., ed. Burocracia e ocupação no setor público brasileiro. Rio de Janeiro: IPEA.

Das, V., 2004. The Signature of the State: The paradox of illegibility. In D. Poole \& V. Das, eds. Anthropology in the Margins of the State. Santa Fe: School of American Research

Desrosières, A., 1993. La politique des grands nombres: histoire de la raison statisque. Paris: La Découverte.d

Floyd, S. \& Wooldridge, B., 1992. Middle Management Involvement in Strategy and Its Association with Strategic Type: A research note. Strategic Management Journal, 13, Special Issue, pp.153-167. DOI: 10.1002/smj.4250131012

Gomide, A. \& Pires, R., eds. 2014. Capacidades estatais e democracia: arranjos institucionais de políticas públicas. Brasília: IPEA.

Gunn, L.A. 1978. Why Is Implementation So Difficult? Management Services in Government, 33, pp.169-76

Gupta, A., 2012. Red Tape. London: Duke University Press.

Heimer, C., 2013. Resilience in the Middle. Annals of American Academy of Political and Social Science, 649(1), pp.139-156. DOI: /10.1177/0002716213491542

Howlett, M., 2011. Public Managers as the Missing Variable in Policy Studies: An empirical investigation using Canadian data. Review of Policy Research, 28(3), pp.247-263. DOI: 10.1111/j.1541-1338.2011.00494.x

Hull, M., 2008. Ruled by Records: The Expropriation of Land and the Misappropriation of Lists in Islamabad. American Ethnologist, 35(4), pp.501-518. DOI: 10.1525/california/9780520272149.003.0005 
Hull, M., 2012. Government of Paper: The Materiality of Bureaucracy in Urban Pakistan. Berkeley: University of California Press.

Huising, R. \& Silbey, S., 2011. Governing the Gap: Forging safe science through relational regulation. Regulation \& Governance, 5(1), pp.14-42. DOI: 10.1111/j.1748-5991.2010.01100.x

Kafka, B., 2012. The Demon of Writing: The Powers and Failures of Paperwork. Brussels: Zone Books.

Knight, F., 1921. Risk, Uncertainty and Profit. Mineola: Dover Publications.

Kuratko, D.; Ireland, R.; Covind, J. \& Hornsby, J., 2005. A Model of Middle-Level Managers' Entrepreneurial Behavior. Enterpreneurship Theory \& Practice, 29(6), pp.699-716. DOI: 10.1111/j.1540-6520.2005.00104.x

Kuschnir, K., 2000. Eleições e representação no Rio de Janeiro. Rio de Janeiro: Relume Dumará.

Lascoumes, P. \& Le Galès, P., 2007. Introduction: Understanding Public Policy through Its Instruments: From the Nature of Instruments to the Sociology of Public Policy Instrumentation. Governance, 20(1), pp.1-21, DOI: 10.1111/j.1468-0491.2007.00342.x

Lascoumes, P. \& Le Galès, P., 2012. A ação pública abordada pelos seus instrumentos. Pós Ciências Sociais, 9(18), pp.19-44.

Lima, L. \& D’ Ascenzi, L., 2017. O papel da burocracia de nível de rua na implementação e (re)formulação da Política Nacional de Humanização dos serviços de saúde de Porto Alegre (RS). Revista de Administração Pública, 51(1), pp.46-63. DOI: $0.1590 / 0034-7612145223$

Lipsky, M., 1980. Street Level Bureaucracy: Dilemmas of the Individual in Public Services, New York: Russell Sage Foundation.

Lopez, F., ed. 2015. Cargos de confiança no presidencialismo de coalizão brasileiro. Brasília: IPEA.

Lotta, G., 2010. Implementação de políticas públicas: o impacto dos fatores relacionais e organizacionais sobre a atuação dos burocratas de nível de rua. Tese de Doutorado. São Paulo: USP.

Lotta, G.; Pires, R. \& Oliveira, V., 2015. Burocratas de médio escalão: novos olhares sobre velhos atores da produção de políticas públicas. In P. Cavalcante \& G. Lotta, eds. Burocracia de médio escalão: perfil, trajetória e atuação. Brasília: ENAP.

Loureiro, M., 1997. Formação das elites político-administrativas no Brasil: as instituições de pesquisa econômica aplicada. Revista do Serviço Público, 48(2), pp.101-123.

Loureiro, M.R. \& Abrucio, F.L., 1999. Política e burocracia no presidencialismo brasileiro: o papel do Ministério da Fazenda no primeiro governo Fernando Henrique Cardoso. Revista Brasileira de Ciências Sociais, 14(41), pp.69-89. DOI: 10.1590/S0102-69091999000300005

Marcus, G., 1995. Ethnography in/of the World System: The emergence of multi-sited ethnography. Annual Review of Anthropology, 24, pp.95-117. DOI: 10.1146/annurev.anthro.24.1.95

Marques, E., 2000. Estado e redes sociais: permeabilidade e coesão nas políticas urbanas no Rio de Janeiro. Rio de Janeiro: Editora Revan.

Medauar, O., 2014. Direito Administrativo Moderno. São Paulo: Revista dos Tribunais.

Meyer, R.; Egger-Peitler, I.; Höllerer, A. \& Hammerschmid, G., 2013. Of Bureaucrats and Passionate Public Managers: Institutional logics, executive identities, and public service motivation. Public Administration, 92(4), pp.861-885. DOI: 10.1111/j.1467-9299.2012.02105.x

Menon, A. \& Sedelmeier, U., 2010. Instruments and Intentionality: Civilian Crisis Management and Enlargement Conditionality in EU Security Policy. West European Politics, 33(1), pp.75-92. DOI: 10.1080/01402380903354106

Moe, T., 1984. The New Economics of Organization. American Journal of Political Science, 28(4), pp.739-777. DOI: 10.1007/0-387-25092-1_13

Mosse, D., 2005. Cultivating Development: An ethnography of aid policy and practice. London: Pluto Press.

Mosse, D., 2006. Anti-Social Anthropology? Objectivity, objection, dam the ethnography of public policy and professional communities. Journal of the Royal Anthropological Institute, 12(4), pp.935-956. DOI: 10.1111/j.1467-9655.2006.00371.x

Nadai, L., 2012. Descrever crimes, decifrar convenções narrativas: uma etnografia entre documentos oficiais da Delegacia de Defesa da Mulher de Campinas em casos de estupro e atentado violento ao pudor. Dissertação de Mestrado. Campinas: Unicamp.

Nader, L., 1972. Up the Anthropologists: Perspectives gained from studying up. In D. Hymes, ed. Reinventing Anthropology. New York: Random House.

Oliveira, J., 2004. Pluralizando tradições etnográficas: sobre um certo mal-estar na antropologia. In E. Langdon \& L. Garnelo, eds. Saúde dos povos indígenas: reflexões sobre antropologia participativa. São Paulo: Contracapa.

Oliveira, A., 2012. Burocratas da linha de frente: executores e fazedores das políticas públicas. Revista de Administração Pública, 46(6), pp.1551-1573. DOI: 10.1590/s0034-76122012000600007

Page, E.C.; \& Jenkins, B., 2005. Policy Bureaucracy: Governing with a cast of thousands. Oxford: Oxford University Press.

Pels, P. \& Salemink, O., 1999. Introduction: Locating the colonial subjects of Anthropology. In P. Pels \& O. Salemink, eds. Colonial Subjects: Essays on the practical history of Anthropology. Ann Arbour: Michigan University Press.

Pereira, A., 2014. A construção de capacidade estatal por redes transversais: o caso de Belo Monte. Tese de doutorado. Brasília: UnB.

Pires, R., 2016. A implementação de políticas públicas nos encontros entre burocratas e destinatários: contribuições da sociologia do guichê. In $40^{\circ}$ Encontro da Anpocs. Caxambu.

Pressman, J. \& Wildavsky, A., 1973. Implementation. Berkeley: University of California Press. 
Riles, A., ed. 2006. Documents: Artifacts of Modern Knowledge. Ann Arbor: University of Michigan Press.

Rodrigues, L., 2016. Análise de políticas públicas: a influência dos street level bureaucrats (burocratas de nível de rua) no processo de implementação da política habitacional do estado de Minas Gerais. Dissertação de Mestrado. Viçosa: Universidade Federal de Viçosa.

Scott, J., 1998. Seeing Like a State: How Certain Schemes to Improve the Human Condition Have Failed. New Haven: Yale University.

Sharma, A. \& Gupta, A., 2006. Introduction: Rethinking theories of the State in the age of globalization. In Sharma, A. \& Gupta, A., eds. Anthropology of the State. Oxford: Blackwell.

Taleb, N., 2012. Antifragile: Things that gain from disorder. New York: Random House

Thomas, R. \& Linstead, A., 2002. Losing the Plot? Middle managers and identity. Organization, 9(1), pp.71-93. DOI: $10.1177 / 1350508402009001356$

Vianna, A., 2014. Etnografando documentos: uma antropóloga em meio a processos judiciais. In S. Castilho; A. Lima \& C. Teixeira, eds. Antropologia das práticas de poder. Rio de Janeiro: Contracapa.

Weber, M., 1978. Economy and Society. Berkeley: University of California.

Weller, J., 1997. Le guichet interactif. Ce que font les bureaucrates lorsqu'ils répondent au téléphone. Réseaux, 15(82), pp.129-148. DOI: 10.3406/reso.1997.3060

Weller, J., 1999. L'état au guichet: sociologie cognitive du travail et modernisation administrative des services publics. Paris: Desclée de Brouwer.

Wise, L., 2004. Bureaucratic Posture: On the need for a composite theory of bureaucratic behavior. Public Administration Review, 64(6), pp.669-680. DOI: 10.1111/j.1540-6210.2004.00414.x

\section{Outras fontes}

Prefeitura do Município de São Paulo. Sistema de Gestão de Pessoas - Sigpec. Disponível em: https://www.prefeitura.sp.gov.br/cidade/secretarias/gestao/portal_do_servidor/sigpec/index.php?p=4062. Acesso em: 22 mar. 2019.

The Political Life of Documents: Notes on bureaucrats, politics and paper

ABSTRACT Introduction: The article addresses a theme still scarcely debated within studies on bureaucracy and public policy: documents as material artifacts and their effects on bureaucrats, public policies, and politics within the State. It aims to promote a debate on the importance of documents as instruments of public action, as well as to propose a new classification for a subtype of middle-level bureaucrats, labeled back-office bureaucrats. Materials and Methods: The research stems from an ethnography on documentation practices that was undertaken during three years in which both authors took park on a wide-scope administrative reform on documentation practices at São Paulo's City Hall. As means of information gathering, it involved participant observation, multiple interviews and a selection of legislation and administrative case files. Results: From this research, we have found that the interaction between the time of politics - which relates to the interactions between incumbent, government officials, bureaucracies and civil society - and the time of paperwork - which is related to the set of rules that establishes modes of record-keeping for bureaucratic activities, degrees of mandatoriness for such activities, and disciplinary control - on back-office bureaucrats is decisive to understanding their behavior, which is aimed at mitigating professional risks. Secondly, we have observed that the set of practices promoted by these bureaucrats reflects a mobilization of a particular set of properties that documents carry within the broader context of bureaucracy: the production of truth, the transposition of old solutions into new contexts and the (lack of evidence of a political deal. Discussion: As a result of these findings, we point to three implications. The first one, the dynamics of bureaucratic action can help explains the tendency for inertia within bureaucracies and public policies, highlighting the need for extensive negotiations and the set of new landmarks of documentation so that innovative projects can succeed within bureaucracies. The second one, the promotion of documentation practices may produce further opacity, as opposed to what open data policies might expect. Finally, this approach points to new issues for the debates of bureaucratic capacities and coordination. When the State is regarded not just from the individual action of its agents and the intertwining of personal networks, but also from the ways the materiality of instruments of action within them can influence said relations, the challenges of political leadership, as well as the task of understanding it, become more complex.

KEYWORDS: documents; middle-level bureaucrats; bureaucracy; public policy; instrumentation of public action.

This is an Open Access article distributed under the terms of the Creative Commons Attribution Non-Commercial License which permits unrestricted non-commercial use, distribution, and reproduction in any medium provided the original work is properly cited. 